\title{
腕神経叢原発神経線維腫に対する 胸腔鏡下外科手術の一治験例
}

桂 敏明, 明石 章則, 大橋 秀一*, 余田 洋右*

鄭 一秀*，笹岡 英明*，坂巻 靖

要

旨

胸神経丵由来で胸腔内進展をきたした神経線維腫に対し，胸腔鏡下摘出術を施行した。患者は50歳の 女性で，検診にて右肺尖部の異常陰影を指摘され手術目的で当科を紹介された。画像診断にて上縦隔か ら発生した良性腫瘍が疑われ胸腔鏡下摘出術を施行した. 上縦隔を占拠している腫瘍は胸神経叢である 第 1 胸椎神経根由来で内視鏡外科用マイク口箭刀を用いて可及的に神経根から腫瘍を切除した. 腫瘍切 除による神経根欠損部を5-0 prolene を用いて胸腔鏡下に修復した。腫瘍の病理組織診は神経線維腫で あった．術後，尺骨神経領域のしびれと握力低下が認められたが，経過とともに次第に回復した. 周囲 臓器に浸潤せず，腫瘍の発生部位が確認可能な神経原性腫瘍は胸腔鏡下摘出術の良い適応と考えられ る.

索引用語：腕神経叢, 神経線維腫, 胸腔鏡下外科手術 brachial plexus, neurofibroma, thoracoscopic surgery

\section{緒言}

minimally invasive surgery としての胸腔鏡 下外科手術は，低侵襲性のためにその適応を拡 大する試みが積極的になされている吕. 我々は 腕神経叢由来で胸腔内に進展した神経叢維腫に 対して胸腔鏡下手術で摘出し，その後神経欠損 部の修復を胸腔鏡下に行ったので文献的考察を 加光報告する.

\section{症例}

患 者：50歳, 女性.

主 訴: 胸部異常陰影.

家族歴：特記すべきことなし：

既往歴：特記すべきことなし。

宝塚市立病院 呼吸器外科, *同 外科

原稿受付 1995年 8 月 14 日

原稿採択 1996年 3 月 22 日
現病歴：検診にて右肺尖部の異常陰影を指摘 された．糖査及び治療目的で当料を紹介され入

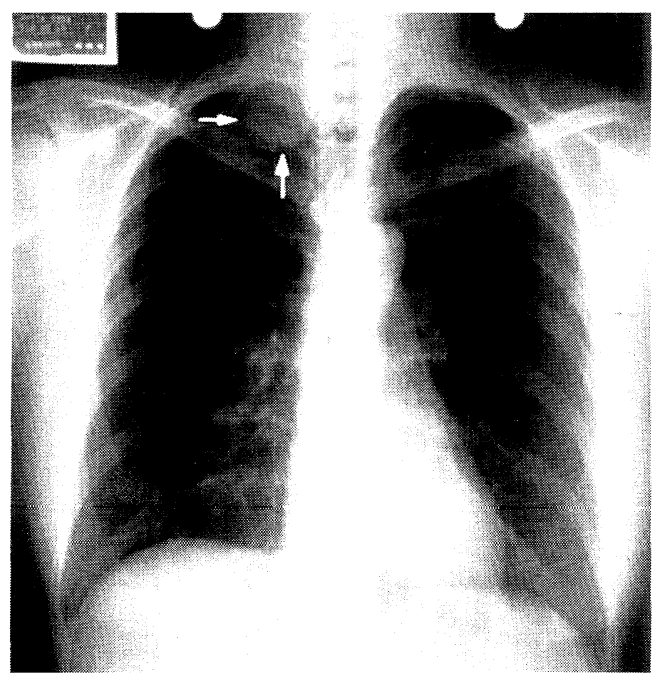

Fig. 1 Chest $\mathrm{X}$-ray showing an abnormal shadow in the right lung apex. 


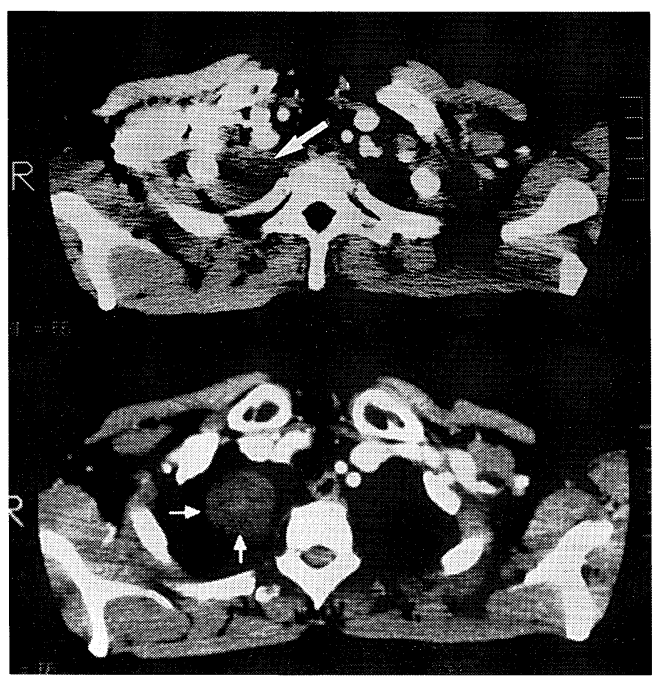

Fig. 2 Chest CT scan showing a mass (arrow) in the right lung which seems to be a benign tumor.

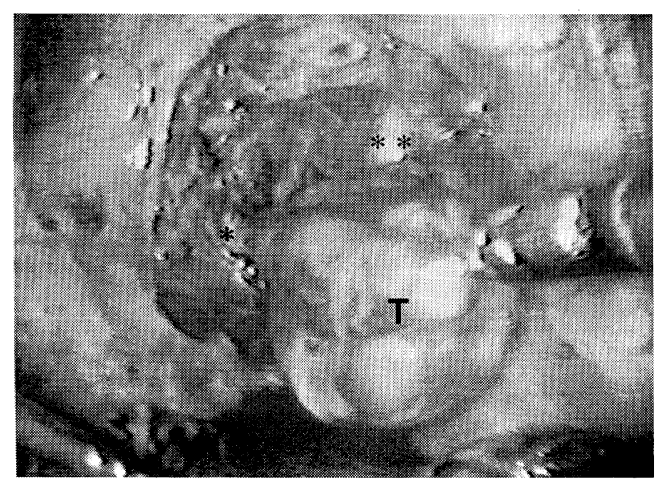

Fig. 3 Tumor ( $\mathrm{T}$ ) arising from the Th1 nerve. proximal site $(*)$ and distal site $(* *)$ positions of Th1 nerve.

院した.

入院時現症：全身状態は良好で右鎖骨上窩か ら腫瘤は触知されなかった，右上肢のしびれ感 などの知覚異常や疼痛, 運動障害は無かった。

胸部 CT 写真：右肺尖部に径 $3 \mathrm{~cm}$ 大，内部 ほぼ均一で円型かつ辺縁明瞭な腫瘤陰影を認め た (Fig. 2). 術前診断は良性肺腫瘍か上縱隔腫 瘍で, 診断と治療を目的として先ずは胸腔鏡下 の摘出術を施行した.

胸腔鏡下手術：全身麻酔下，左側臥位で左片 肺換気にした. 第 4 肋間前腋窩線と第 5 肋間中

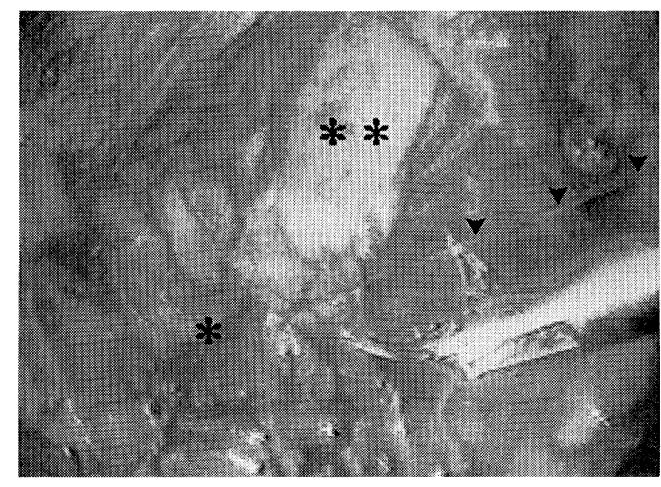

Fig. 4 Repair of the nerve (Th1) by direct sutures between proximal $(*)$ and distal $(* *)$ sides of defect. $\boldsymbol{\Delta}$, thread

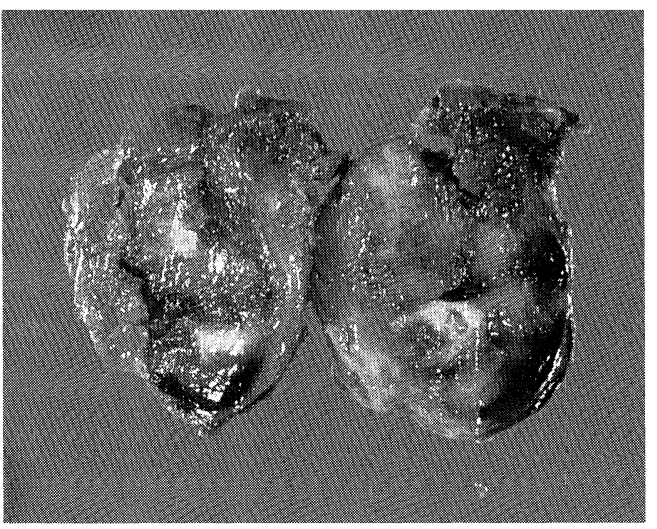

Fig. 5 Macroscopic appearance of tumor.

腋窩線に内視鏡下鉗子器具用のトラコポートを， 第 7 肋間後腋窩線には胸腔鏡用トラコポートを 留置して手術を施行した. 腫瘍は大きさが約 3 $\mathrm{cm}$ で，その周囲が第一胁骨に囲まれた胸郭入 口部から胸腔内に突出していた。壁側胸膜を腫 瘍の全周に沿って切離し, 腫瘍を周囲組織から 慎重に剥離すると第 1 胸椎の神経根から発生し ていることが判明した．腫瘍は腕神経叢である 第 1 胸椎神経根由来 (Fig. 3) で, 神経と腫瘍と の境界は不明瞭で剥離が困難であった．神経根 を可能な限り温存するために腫瘍と神経との境 界付近の神経根側をマイクロ剪刀を用いて可及 的に腫瘍を切除した. 術中迅速病理組織診断で は良性の神経原性腫瘍であった．腫瘍切除によ る神経根欠損部を5-0 prolene を用いて胸腔鏡 


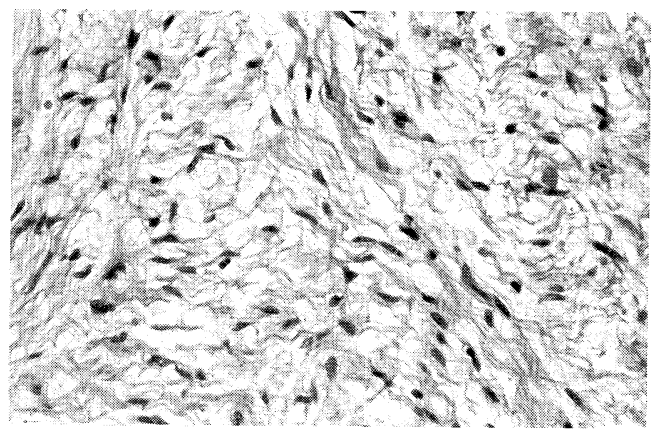

Fig. 6 Microscopic appearance of tumor.

下に結節縫合にて修復した（Fig. 4).

摘出標本: 周辺結合織との境界は明瞭で, 充 実性の腫瘍であった（Fig. 5).

病理組織学的検査: 組織学的には良性の神経 線維腫であった（Fig. 6). 摘出した腫瘍の第 1 胸椎神経根側の切離面には腫瘍細胞が認められ た。

術後経過：術直後より右上腕内側から前腕内 側の尺骨神経領域に掞けるしびれ, 感覚純麻, 脱力感を認め, 握力は右 $5 \mathrm{~kg}$, 左 $27 \mathrm{~kg}$ と右握 力が著明に低下した. 術後 2 日目に胸腔ドレー ンを抜去， 4 日目に退除した. 術後 6 力月後の 上肢のしびれ領域は減少して掞り，右掘力も 20 $\mathrm{kg}$ まで回復した. また尺骨神経支配の母指内転 筋，尺側手根筋群，小指外転筋の筋電目に拈い て MCV (運動神経伝達速度), SCV (知覚神経 伝達速度）の異常は認められず，特に母指内転 筋においては多相性活動電位が認められるなど 神経再支配の所見が認められた.

現在までのところ再発は認められていない。

\section{考察}

良性縱隔腫瘍は胸腔鏡下摘出術の良い適応で ある4). その手技を用いて腫瘍を摘出するとき には, 腫瘍と気管・気管支, 食道, 大動静脈や 神経などの周囲臓器との解剖学的な局在位置関 係を考慮し，慎重に剥離操作を進めることが重 要である. 自験例は胸腔鏡検査で胸神経叢から 発生し胸腔内へ突出した腫瘍である事が判明し た（Fig. 7).引き続いて胸腔鏡下の摘出術に移 り, 奥深い腕神経叢に位置している腫瘍の剥離

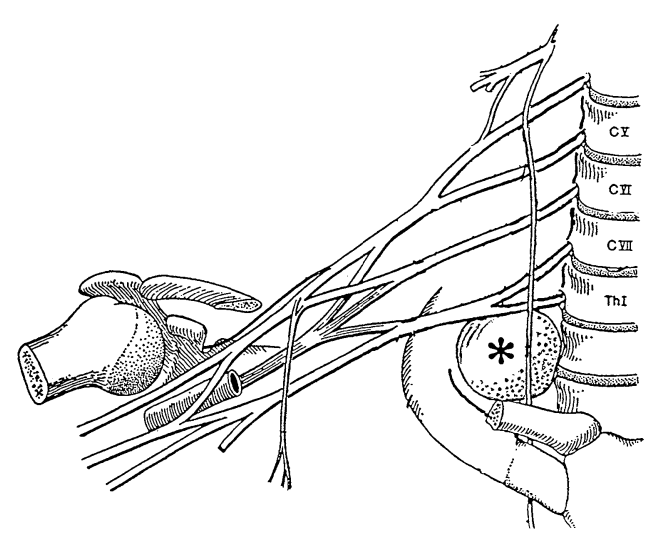

Fig. 7 Diagram of tumor (*) arising in the brachial plexus.

操作を行った.テレビモニターの画面上に腫瘍 の局所部位が拡大されて映し出されるために, 腕神経叢の神経束・神経根, 腕頭動脈, 鎖骨下 動脈などの周囲臓器と腫瘍との位置関係を把握 することが可能で, 容易に腫瘍の剝離操作を行 い得た。

しかし, 神経原性腫瘍を腕神経叢の Th1 神経 根から切離する際にその正常神経組織と腫瘍と の境界をテレビモニター上判別することは困難 であった. 術後の神経障害を防ぐために正常神 経組織を可能な限り温存する心要があるが，神 経線維腫は病理組織学的に神経鞘と神経線維か ら由来していて被膜を有していない(5)ために, 正常神経組織と腫瘍との境界をテレビモニター 上判別することが難しいと考えられる6). 腫瘍 部分と正常な神経部分との区別が肉眼的に困難 で, マイクロ剪刀を用いて神経根から腫瘍を可 及的に切除した. 摘出した腫瘍の第 1 胸椎神経 根側の切離面には腫瘍細胞が認められたために, 再発に対する厳重な経過観察が必要である.

腕神経叢原発で胸郭内に進展した神経原性腫 瘍についての手術報告例は, 我々が文献上検索 し得た限り自験例を含めて 3 例 6 ,7)であった (Table 1). 術後の後遺症は, 後側方切開から の開胸術で摘出した神経鞘腫の 1 例が術後にホ ルネル症候群を認めた. しかし，この合併症の 原因ついての記載は無く不明である，鎖骨上窩 からのアプローチで摘出した神経鞘腫は術後合 
Table 1 Cases of neurogenic tumor arising in the brachial plexus with intrathoracic extension.

\begin{tabular}{|c|c|c|c|c|}
\hline Case & Age $\cdot$ Sex & Operative approach & Pathology & Complication \\
\hline$(1)$ & $56 \cdot \mathrm{F}^{5)}$ & Thoracotomy & Neurilemmoma & Horner's syndrome \\
\hline$(2)$ & $54 \cdot \mathrm{F}^{6)}$ & Supraclavicular approach & Neurilemmoma & Nothing \\
\hline$(3)$ & $50 \cdot \mathrm{F}$ & Thoracoscopic surgery & Neurofibroma & Ulnar nerve palsy \\
\hline
\end{tabular}

併症を認めなかった，文献的には経頸部非開胸 下のアプローチで腫痬を摘出しても, 術後重篤 な神経障害をきたした症例が報告8されて招り， 腫瘍切障の際に神経欠損が生じた場合には速や かに神経再建を行らことが望ましい(8)と言われ ている。また，明らかに縱隔腫瘍との診断が可 能であれば経頸部的摘出も考慮可能だが, 自験 例のように肺実質内の腫瘍も否定出来ない場合， 経頸部的アプローチは不可欠である.

周囲臓器に浸潤せず胸腔内に突出した腕神経 叢発生の神経原性腫瘍は, 胸腔鏡下摘出術の良 い適応と考兄られる. しかし, 術後の神経障害 を防ぐために正常神経組織を可能な限り温存し て術後の神経障害を回避する必要があるが, 腫 瘍切除の際に神経欠損が生じた場合には速やか に神経再建を行うことが望ましく慎重な対応が 必要である。

\section{文献}

1) Landreneau RJ, Dowling RD, Castillo WM, et al: Thoracoscopic resection of an anterior mediastinal tumor. Ann Thorac Surg 54 : 142 $-144,1992$.

2）明石章則, 大橋秀一, 余田洋右, 他：自然気胸 50 例に対する胸腔鏡下外科手術の治療経験. 日 呼外会誌 7:798-802, 1993.

3）鄭 一秀, 明石章則, 大橋秀一, 他：外傷性血 気胸に対する緊急胸腔鏡検查及び手術の一治 験例. 日呼外会誌 8:840-844, 1993.

4) Sugarbaker DJ : Thoracoscopy in the management of anterior mediastinal masses. Ann Thorac Surg 56 : 653-656, 1993.

5) Shield TW : Primary lesions of the mediastinum and their investigation and treatment. In General thoracic surgery edited by Shield TW., William \& Wilkins, Philadelphia, pp 1725-1769,1994.

6) Phalen GS : Neurilemmomas of the forearm and hand. Clin Orthop $114:$ 219-222, 1976.

7) Gyhra A, Israel J, Santander C, et al: Schwannoma of the brachial plexus with intrathoracic extension. Thorax 35 : 703-705, 1980.

8）野守裕明，三村 孝，鈴木信正，他：胸郭内進 展をした腕神経叢原発神経鞘腫の 1 例. 日臨外 会誌 51：1594-1596, 1990.

9）畑 洋, 西島直城, 井戸一博, 他：神経再建 を必要とした腕神経叢内神経原性腫瘍の 3 症 例. 臨整外 29:611-615, 1994.

\title{
Neurofibroma in brachial plexus with intrathoracic extension removed by thoracoscopic surgery; a case report
}

\author{
Toshiaki Katsura, Akinori Akashi, Shuichi Ohashi*, Yousuke Yoden*, Hiroki Kanno* \\ Kazuhide Tei*, Hideaki Sasaoka*, Yasushi Sakamaki, Masayuki Nishino*
}

Departments of Thoracic Surgery and Surgery*, Takarazuka City Hospital, Japan

A 50-year-old female had an abnormal shadow on a routine chest rentogenogram. Computed tomography suggested a beningn tumor in the right upper mediastinum, so we performed thoracoscopic surgery. The tumor was found in the brochial plexus. After operation she had ulnar nerve palsy, but gradually recovered. The pathological diagnosis was neurofibroma. We think that thoracoscopic surgery is indicated for mediastinal tumors with intrathoracic extension, but it is necessary to consider the histological type and the anatomical position of the tumor. 